\title{
ANALISIS PERAN GURU DALAM MEMBANTU INTERAKSI ANAK BERKEBUTUHAN KHUSUS
}

\author{
${ }^{1}$ Amalia Risqi Puspitaningtyas \\ ${ }^{1}$ FKIP, PGSD, Universitas Abdurachman Saleh \\ Email: amaliarisqipuspitaningtyas@ gmail.com
}

Received: Nov 14, 2020 Revised: Nov 20, 2020 Accepted: Dec 11, 2020

\begin{abstract}
ABSTRAK
Interaksi sosial merupakan hal yang penting dilakukan oleh seluruh siswa ketika sedang melakukan pembelajaran di sekolah baik bagi anak berkebutuhan khusus ataupun siswa reguler. Anak berkebutuhan khusus mengalami kesulitan dalam berinteraksi dengan lingkunganya. SDN kilensari 2 merupakan sekolah inklusi dimana anak berkebutuhan khusus dan siswa reguler belajar dalam satu kelas yang sama, hal ini mampu membantu anak berkebutuhan khusus berinteraksi dengan teman reguler dengan bantuan dari guru. Bentuk interaksi yang di lakukan oleh guru yaitu kerjasama, guru bekerjasama dengan guru pendamping untuk mengenal anak berkebutuhan khusus terkait pemberian materi, tugas dan nilai dan bekerjasama dengan siswa reguler untuk tidak membandingkan anak berkebutuhan khusus dengan siswa lainnya. Interaksi selanjutnya yaitu asimilasi, guru pengajar dalam membimbing anak berkebutuhan khusus tidak takut untuk berinteraksi dengan siswa reguler.
\end{abstract}

Kata Kunci: Peran Guru, Interaksi, Anak Berkebutuhan Khusus

\section{ABSTRACT}

Social interaction is an important thing for all students to do when they are learning at school, both for children with special needs and regular students. Children with special needs have difficulty in interacting with their environment. SDN Kilensari 2 is an inclusive school where children with special needs and regular students study in the same class; this is able to help children with special needs interact with regular friends with help from the teacher. The form of interaction carried out by the teacher is cooperation; the teacher collaborates with the accompanying teacher to get to know children with special needs related to the provision of materials, assignments and grades and collaborates with regular students not to compare children with special needs with other students. The next interaction is assimilation, teaching teachers in guiding children with special needs are not afraid to interact with regular students.

Keywords: Teacher's Role, Interaction, Children With Special Needs 


\section{PENDAHULUAN}

Dalam pendidikan seorang guru memiliki peran sebagai perencana, pelaksana, penilai, dan pembimbing. Maka salah satu tugas utama dari seorang guru adalah berusaha untuk membantu dan membimbing siswa dalam proses belajar menAnak berkebutuhan khusus adalah anak yang memiliki kelainan fisik, mental, emosional, sosial dan memiliki potensi kecerdasan atau bakat istimewa sehingga perlu mendapatkan pelayanan pendidikan yang sesuai dengan kebutuhan dan hak asasinya (Permendiknas,70:2009). Anak berkebutuhan khusus selain belajar akademik juga belajar berinteraksi dengan teman sesama berkebutuhan khusus dan orang-orang normal dilingkungan sekitarnya.

Keterbatasan anak berkebutuhan khusus seringkali menyebabkan mereka menarik diri dari sosialisasi di kelas dimana anak yang normal mempunyai prestasi yang jauh di luar jangkauannya. Dengan demikian peran guru pendamping sangat penting untuk memberikan motivasi serta bantuan untuk memecahkan permasalahan yang dialami anak berkebutuhan khusus tersebut.

UNESCO (lembaga PBB yang menangani pendidikan di dunia) menegaskan bahwa inklusi dan kesamaan adalah prinsip yang menjadi kunci dalam pendidikan. Pernyataan ini dimasifkan diseluruh dunia, termasuk di indonesia. Undang- undang republik indonesia No 20 Tahun 2003 tentang sistem pendidikan nasional memberikan warna lain dalam penyediaan pendidikan bagi anak berkelainan. Pasal 15 tentang penddikan khusus menyebutkan bahwa pendidikan khusus merupakan pendidikan untuk peserta didik yang berkelainan atau peserta didik yang memiliki kecerdasan luar biasa yang diselenggarakn secara inklusif atau berupa satuan pendidikan khusus pada tingkat pendidikan dasar dan menengah. Anak berkebutuhan khusus akan belajar bersama anak reguler guna semakin mengoptimalkan potensi yng dimilikinya, sehingga anak Berkebutuhan Khusus mendapat kesempatan bersosialisa dengan banyak orang.

Salah satu hal yang diutamakan dalam pendidikan inklusi adalah anak berkebutuhan khusus yang dalam proses pertumbuhan atau perkembangnya mengalami kelainan atau penyimpangan fisik, mental-intelektual, sosial dan emosional dibandingkan anak-anak lain seusianya. Anak berkebutuhan khusus memerlukan pelayanan pendidikan khusus karena perbedaan yang dimilikinya. Pelayanan anak 
berkebutuhan khusus bisa dengan sekolah khusus, guru khusus atau penanganan yang khusus sesuai dengan kelainannya. Pendidikan dan pengajaran terhadap anak berkebutuhan khusus membutuhkan suatu pola tersendiri sesuai dengan kebutuhan masing- masing. Penerapan strategi yang baik dan benar akan menciptakan lingkungan kelas yang kondusif. Keadaan kelas yang kondosif dan nyaman untuk belajar anak berkebutuhan khusus dan siswa reguler akan menciptakan sebuah interaksi sosial yang baik. Interaksi sosial merupakan hubungan antar individu dimana mereka saling mempengaruhi dan terdapat hubungan timbal balik. Individu yang dimaksud disini bisa dari pimpinan sekolah, guru, siswa dan pegawai sekolah. Jika terdapat interaksi yang baik di sekolah atau kelas maka akan tercipta suasana kelas yang hidup, siswa kreatif dan responsif. Sebaliknya jika interaksi kurang baik maka kelas akan seperti mati, siswa pasif dan kurang responsif.

Interaksi selalu terjadi anatara guru dan siswa dalam setiap kegiatan belajar mengajar, baik itu siswa reguler maupun siswa berkebutuhan khusus (dalam sekolah inklusi). Sebagai mahluk sosial, siswa juga butuh untuk berinteraksi dan berkomunikasi dengan sesama. Lingkungan sekolah merupakan faktor yang penting dalam pembentukan karakter. Siswa akan banyak menghabiskan waktunya untuk belajar dan berinteraksi di sekolah. Jika interaksi yang dilakukan baik maka perkembangan ke masa depan akan lebih baik. Kedekatan guru dengan murid akan menciptakan keadaan lingkungan yang hangat dan bersahabat. Keterbukaan siswa akan terjadi dengan sendirinya jika terjadi komunikasi yang baik dilingkungan sekolah, maka dari itu guru memiliki peran penting dalam interaksi siswanya. Peran guru penting diperlukan karena sebagai pendidik, fasilitator atau motivator kepada anak agar bisa berkembang dalam interaksi sosialnya. Jika interaksi bisa diarahkan dengan baik maka akan menghasilkan interaksi sosial yang baik pula.

Interaksi sosial anak berkebutuhan khusus akan berbeda kemampuannya dengan siswa normal tergantung jenis kelainan yang dialami. Apalagi masih kelas awal yang dalam proses adaptasi dengan sekolah dan lingkungnya, karena mereka juga masih mengalami perkembangan non verbalnya. Seorang guru SD harus tahu bagaimana sikap yang harus diberikan kepadaAnak Berkebutuhan Khusus dan cara yang tepat dalam mengajar anak di sekolah inklusi, karena ABK dalam kegiatan belajar akan mengalami kesulitandalam menangkap pelajaran secara normal. Jika semua guru mengerti tentang 
pendidikan inklusi, maka inklusi tidak hanya akan menjadi harapan belaka, karena akan sangat bagus jika menjadi sebuah tujuan pendidikan bagi semua siswa termasuk yang berkebutuhan khusus. Inklusi memberikan hak yang sama dan kesempatan bagi ABK yang ingin merasakan lingkungan pendidikandengan siswa normal

Kelemahan anak berkebutuhan khusus juga terdapat dalam hal mental, kematangan emosional dan interaksi sosialnya. Anak berkebutuhan khusus jarang mau berinteraksi dengan sekitarnya jika tidak diajari. Kematangan emosional anak berkebutuhan khusus sulit untu7k stabil, bisa berubah anatar baik ke buruk secara drastis. Guru pendamping khusus sangat membantu dalam perkembnagan anak berkebutuhan khusus agar bisa bersosial dengan lingkunganya. Masalah dalam pengkondisian lingkungan biasanya anak berkebutuhan khusu sering terlibat konflik, persaingan karena ingin diperhatikan bahkan bisa sampai menarik diri dari proses pembelajaran. Guru juga bisa menggunakan strategi belajar yang cocok untuk membantu interaksi anak, seperti menggunakan metode kerja kelompok yang terbukti efektif dalam meningkatkan interaksi sosial siswa.

Salah satu SD yang menyelenggarakan sekolah inklusi yaitu SDN 2 Kilensari Kecamatan Panarukan yang merupakan sekolah rujukan bagi anak berkebutuhan khusus yang ada di kabupaten Situbondo. Jenis Anak Berkebutuhan Khusus yang ada di sekolah tersebut yaitu autisme, tuna Rungu dan downsyndrome. Di Sekolah tersebut memulai menerima anak berkebutuhan khusus pada tahun ajaran 2018 hingga sampai saat ini dan sekolah tersebut salah satu sekolah inkusi yang ada di kecamatan panarukan yang juga menjadi salah satu sekolah rujukan bagi anak berkebutuhan khusus yang tidak hanya berdomisili di daerah tersebut akan tetapi dari kecamatan besuki juga bersekolah di SDN 2 kilensari.

Dalam proses pembelajaran bagi anak berkebutuhan khusus di SDN 2 Kilensari guru melakukan berbagai inovasi agar peserta didik dapat mengikuti proses pembelajaran dengan baik. Interaksi antara anak berkebutuhan khusus dengan siswa reguler dan guru pengajar penting untuk diteliti agar mampu memberikan pendekatan yang tidak menyulitkan anak berkebutuhan khusus dalam proses pembelajaran. Hal ini memberikan pemahaman terhadap masyarakat bahwa peserta didik Berkebutuhan Khusus juga dapat bersekolah di sekolah umum 
bukan hanya bersekolah di Sekolah Luar Biasa(SLB). Dari berbagai hal tersebut peneliti tertarik untuk meneliti interaksi anak berkebutuhan khusus di SDN 2 Kilensari kec.Panarukan.

\section{METODE PENELITIAN}

Menurut Sugiyono (2016), metode penelitian kualitatif adalah metode penelitian yang berlandaskan pada filsafat postpositivisme, digunakan untuk meneliti pada kondisi obyek yang alamiah, dimana peneliti adalah sebagai instrumen kunci dan hasil penelitian kualitatif lebih menekankan pada makna daripada generalisasi.

Pendekatan dalam penelitian ini menggunakan pendekatan kualitatif, karena permasalahan belum jelas, holistik, kompleks, dinamis dan penuh makna. Selain itu, peneliti bermaksud memahami situasi sosial secara mendalam, menemukan pola, hipotesis dan teori. Penelitian lapangan dengan penelitian kualitatif ini membantu peneliti mengeksplorasi bagaimana bentuk peran guru dalam inetraksi anak berkebutuhan khusus. Kehadiran peneliti dalam penelitian ini dilakukan secara partisipatif, karena peneliti akan ikut serta dalam proses belajar mengajar di dalam kelas, peneliti akan melihat secara langsung cara memotivasi dan bimbingan yang dilakukan guru terhadap anak berkebutuhan khusus dalam berinteraksi dengan siswa reguler.

Diharapkan dengan melakukan observasi partisipatif, peneliti akan memperoleh data yang lebih lengkap mengenai bimbingan yang dilakukan guru terhadap mahasiswa di kampus tersebut. Selain itu, peneliti harus bersikap objektif dan netral, sehingga nantinya hasil penelitian tidak berat sebelah atau memihak pada kelompok atau orang tertentu.

Data dalam penelitian kualitatif tidak berupa angka-angka, tetapi berupa narasi (kata- kata), gambar, foto-foto dan lainnya. Data dalam penelitian merupakan bagian paling terpenting untuk mengupas persoalan- persoalan penelitian. Data diartikan sebagai bahan materi yang berisikan informasi, keterangan, dan fakta terkait persoalan penelitian. Diantara pengumpulan data yang akan peneliti lakukan meliputi: peran dosen, bentuk dan cara menumbuhkan motivasi, serta faktor pendorong dan penghambat motivasi. Sementara untuk memperoleh data tersebut, peneliti menggalinya melalui sumber hidup, yaitu siswa anak berkebutuhan khusus dan guru di SDN 2 Kilensari Prosedur pengumpulan data merupakan langkah yang paling strategis dalam penelitian, karena tujun utama dari penelitian adaah mendapatkan data. Sugiyono, dalam bukunya "Metode Penelitian 
Kuantitatf, Kualitatif dan R\&D” (2016: 224), membagi prosedur pengumpulan data menjadi empat macam : prosedur observasi, prosedur wawancara, prosedur dokumentasi, dan prosedur triangulasi/gabungan.

Dalam penelitian ini, observasi yang peneliti lakukan lebih pada observasi partisipatif dan bservasi terbuka/terus terang. Observasi partisipatif adalah observasi dimana peneliti terlibat dengan kegiatan sehari-hari orang yang sedang diamati atau yang digunakan sebagai sumber data penelitian Sedangkan observasi terbuka adalah observasi dimana peneliti dalam melakukan pengumpulan data menyatakan terus terang kepada sumber data, bahwa sedang melakukan penelitian, Sugiyono (2016: 227-228). Jadi, yang diteliti mengetahui sejak awal sampai akhir tentang aktivitas peneliti.

Dalam upaya kevalidan data penelitian ini di SDN 2 Kilensari Situbondo, maka peneliti melakukan penelitian melalui observasi langsung selama kegiatan berlangsung. Observasi yang dilakukan terhadap tingkah laku anak berkebutuhan khusus selama selama kegiatan proses belajar mengajar di kelas dan peran guru dalam memberikan motivasi pada siswa anak berkebutuhan khusus dan siswa reguler, sehingga dapat memberikan data tambahan terhadap hasil wawancara. Dalam pelaksanaan kegiatan ini, peneliti hanya melakukan pengamatan dan mencatat data sesuai kenyataan yang ada.

Wawancara merupakan pertemuan dua orang untuk bertukar informasidan ide melalui tanya jawab, sehingga dapat dikonstruksikan makna dalam suatu topik tertentu, Esterberg dalam Sugiyono (2016: 231). Sedangkan Stainback dalam Sugiyono (2016: 232) menjelaskan, dengan wawancara, maka peneliti akan mengetahui hal-hal yang lebih mendalam tetntang partisipan dalam menginterpretasikan situasi dan fenomena yang terjadi, dimana hal ini tidak bisa ditemukan melalui observasi. Dokumen yang dapat diambil diantaranya, yaitu data siswa, data guru, kegiatan proses belajar mengajar, sarana dan prasarana, profil sekolah, adminitrasi mengajar.

\section{ANALISIS DATA}

Pada tahapan selanjutnya dalam penelitian ini adalah analisi data. Analisis data merupakan proses akhir setelah data sudah terkumpul semua, dimana melalui analisi data ini, data yang diperoleh dapat difahami, disimpulkan, dan ditafsirkan. Sebagaimana yang disampaikan Bogdan dalam

Sugiyono (2016: 243), analisis data adalah proses mencari dan menyusun secara sistematis data yang diperoleh dari hasil wawancara, catatan lapangan, dan bahan- 
bahan lain, sehingga mudah difahami, dan temuannya dapat dinformasikan kepada orang lain. Susan Stainback dalam buku Sugiyono (2014:244) mengemukakan bahwa analisis data merupakan hal yang kritis dalam proses penelitian kualitatif.

\section{REDUKSI DATA}

Menurut Sugiyono (2016: 247) Reduksi data diartikan sebagai proses merangkum, memilih hal-hal yang pokok, memfokuskan pada hal-hal yang penting, dicari tema dan polanya. Dengan demikian data yang direduksi akan memberikan gambaran yang lebih jelas dan mempermudah peneliti untuk melakukan pengumpulan data selanjutnya dan mencarinya bila diperlukan. Reduksi data berlangsung terus menerus selama dan sesudah penelitian di lapangan, sampai laporan akhir tersusun.

\section{PENYAJIAN DATA}

Penyajian data merupakan rangkaian kalimat yang disusun secara logis dan sistematis dan bisa dilakukan dalam bentuk uraian singkat, bagan, hubungan antar kategori, flowchart dan sejenisnya. Kemampuan manusia sangat terbatas dalam menghadapi catatan lapangan yang bisa jadi mencapai ribuan halaman (Sugiyono, 2016: 249). Oleh karena itu, diperlukan penyajian data yang jelas dan sistematis dalam membantu peneliti menyelesaikan pekerjaanya.

\section{HASIL DAN PEMBAHASAN}

Dari hasil penelitian ini di temukan beberapa bentuk terjadinya interaksi, diantaranya bentuk kerja sama dan asimilasi. Di SDN 2 Kilensari menerima anak berkebutuhan khusus dan membantu dalam besosialaisasi dengan siswa reguler, guru pengajar sehingga interaksi dalam proses pembelajaran berjalan dengan baik. Interaksi guru dengan murid berkebutuhan khusus yang mana harus menyampaikan materi pembelajaran dengan mudah yang dapat diterima dan dipahami oleh murid berkebutuhan khusus. Penyampaian komunikasi dalam kelas saat proses belajar mengajar dengan informasi yang disampaikan harus sederhana dan mudah di pahami oleh anak berkebutuhan khusus seperti memberi petunjuk dan pengarahan dalam pembelajaran. Tujuan dalam interaksi ini adalah untuk membantu anak berkebutuhan khusus dalam perkembangan pendidikannya. Interaksi sosial sebagai hubunganhubungan sosial yang dinamis. Interaksi merupakan syarat terjadinya antara pendidikan di sekolah, keluarga, dan masyarakat terdapat saling keterkaitan, terutama guru dan anak didik merupakan dua sosok yang tidak dapat dipisahkan dari dunia pendidikan. 
Interaksi yang ada di SDN 2 Kilensari antara guru pengajar dengan murid berkebutuhan khusus berjalan dengan baik, sebaliknya siswa reguler bisa berinteraksi dengan siswa berkebutuhan khusus. Hal pertama yang mendasari interaksi guru pengajar dengan murid berkebutuhan khusus yaitu tidak membandingkan murid berkebutuhan khusus dan siswa reguler yang lainnya. Tidak melihat kekurangan yang dimiliki oleh murid berkebutuhan khusus saat melakukan interaksi dalam proses pembelajaran. Bentuk interaksi edukatif Guru pengajar yang ada di SDN Kilensari 2 ini memberikan perhatian yang sama kepada seluruh siswa.

Guru pengajar memberikan edukasi kepada siswa reguler terkait teman kelasnya yang berbeda yaitu anak berkebutuhan khusus agar mereka bisa berinteraksi dengan baik. Untuk pemeberian tugas dan nilai bagi anak berkebutuhan khusus di berikan standart khusus yang tidak sama dengan siswa reguler. Akan Hal tersebut seperti penjelasan dari Suyono (Suyono, 2015) selain itu guru juga harus sadar bahwa siswa memiliki perbedaan kecerdasan akademis atau intelektual, dalam hal ini ada siswa yang cepat belajar dan ada yang lambat belajar.. Guru pengajar selalu bekerjasama dengan guru pendamping dalam proses belajar mengajar agar anak berkebutuhan khusus dapat mengikuti pembelajaran dengan baik.

Hal tersebut seperti penjelasan dari Soekanto (Soekanto, 2017) bahwa kerjasama timbul apabila orang menyadari bahwa mereka mempunyai kepentingan-kepentingan yang sama dan pada saat bersamaan mempunyai cukup pengetahuan dan pengendalian terhadap diri sendiri untuk memenuhi kepentingan-kepentingan tersebut. Di SDN 2 Kilensari memiliki siswa berkebutuhan khusus dengan berbagai jenis ketunaan yang berbeda dalam satu kelas tersebut, langkah awal yang guru pengajar lakukan yaitu mengenali anak berkebutuhan khusus tersebut sebelum proses pembelajaran berlangsung. Pengenalan yang dilakukan oleh guru pengajar tersebut merupakan cara yang efektif bagi guru dalam melakukan pendekatan dengan murid seperti apa yang disukai dan tidak disukai oleh murid berkebutuhan khusus. Seperti penjelasan dari Sardiman (dalam Edi Suardi, 2012) bahwa interaksi belajar-mengajar ditandai dengan satu penggarapan materi yang khusus. Dalam hal materi harus didesain sedemikian rupa, sehingga cocok untuk mencapai tujuan. Dalam hal ini guru pengajar perlu memperhatikan komponen- komponen pengajaran yang disesuaikan dengan 
karakteristik anak berkebutuhan khusus, seperti materi pembelajaran harus sudah didesain dan disiapkan sebelum berlangsungnya proses pembelajaran.

Bentuk interaksi kedua asimilasi yaitu adanya ketakutan dalam diri anak berkebutuhan khusus saat bersosialisasi dengan teman barunya, karena merasa berbeda dan memiliki keterbatasan. Dalam proses pembelajaran anak berkebutuhan khsuus juga cenderung selalu diam atau sibuk dengan aktifitasnya, sehingga guru pengajar dan guru pendamping akan mengarahkan dan membimbing murid berkebutuhan khusus agar tidak takut dengan siswa reguler.

Seperti pendapat Soekanto (Soekanto, 2017) bahwa asimilasi ditandai dengan adanya usaha-usaha untuk mengurangi perbedaan-perbedaan dan juga meliputi usaha untuk mempertinggi kesatuan tindak, sikap dan prosesproses mental dengan memperhatikan kepentingan-kepentingan dan tujuan bersama. Sebelum melakukan pembelajaran, guru pengajar akan melihat terlebih dahulu dengan mengecek muridnya baik anak berkebutuhan khusus maupun siswa reguler, dalam hal ini lebih melihat kondisi emosinal anak berkebutuhan khusus agar mereka bisa mengikuti pembelajaran dengan baik sesuai rencana pembelajaran. Guru hanya dapat mengetahui apa yang disukai dan tidak disukai murid berkebutuhan khusus tanpa adanya sarana penunjang sistem pendidikan inklusif. Ada beberapa guru pengajar yang masih kurang memahami murid berkebutuhan khusus dalam bekomunikasi. Hal tersebut merupakan kekurangan yang dimiliki oleh sebagian guru pengajar. Selain itu, guru pengajar juga tidak selalu memperhatikan anak berkebutuhan khusus saat mengajar, sehingga ada saja murid berkebutuhan khusus yang tidak fokus atau perhatiannya teralihkan saat proses pembelajaran berlangsung. Hal tersebut merupakan kekurangan yang terjadi saat di dalam kelas dan guru pengajar perlu untuk mengembangkan ketrampilan dan pemahaman mengenai pendampingan anak berkebutuhan khusus.

\section{KESIMPULAN}

Berdasarkan hasil penelitian dalam pembahasan yang telah diuraikan di atas dapat disimpulkan bahwa peran guru pengajar dalam membantu interaksi anak berkebutuhan khusus di SDN 2 Kilensari sangat penting agar mereka bisa bersosialisasi dengan siswa reguler. Bentuk Interaksi yang guru berikan untuk anak berkebutuhan khsus yaitu terbagi menjadi 3 (tiga) bentuk pertama, kerjasama yaitu guru pengajar dan guru pendamping anak berkebutuhan khusus dan siswa reguler yang lainnya dan dalam 
proses pembelajaran dengan terlebih dahulu mengenali murid berkebutuhan khusus sebelum proses pembelajaran berlangsung, kerjasama guru pengajar dan guru pendamping dalam proses pembelajaran yang meliputi pemberian nilai dan tugas. Kedua asimilasi, yaitu adanya usaha dari guru pengajar dan guru pendamping dalam membimbing, mengarahkan anak berkebutuhan khusus untuk bisa berinteraksi dengan siswa reguler agar mereka bisa mengikuti proses pembelajaran dengan baik.

\section{DAFTAR PUSTAKA}

Bandi Delphie, Pembelajaran Anak Tunagrahita; Suatu Pengantar Dalam Pendidikan Inklusi (Bandung: PT. Refika Aditama, 2006).

Bimo Walgito, Psikologi Sosial .Yogyakarta:ANDI, 2003.

Hikmah Risqi Awalia, 'Studi Deskriptif Kemampuan Interaksi Sosial Anak Tunagrahita Ringan',

Jurnal Pendidikan Khusus, 2016,

J David Smith, Inklusi, Sekolah Ramah Untuk Semua .Bandung: Nuansa, 2006.

Rini Rahayu, 'Peran Guru Dalam Mengembangkan Interaksi Sosial Anak Autis Di SD Al Firdaus', 2017

Soekanto, S. (2017). Sosiologi Suatu Pengantar. Rajawali Pers

Sugiyono. (2013). Metode Penelitian Kuantitatif, Kualitatif, dan R \& D. Alfabeta.

Suyono, H. (2015). Implementasi Belajar dan Pembelajaran. PT Remaja Rosdakarya Offset.

UNESCO Education Sector, A Guide for Ensuring Inclusion and Equity in Education, Unesco, 2017

<https://doi.org/ED-2009/WS/31>.

Undang-Undang Republik Indonesia No 20 Tahun 2003 Tentang Sistem Pendidikan Nasional 